\title{
MODIFIKASI KAPAL PURSE SEINE 30 GT DENGAN MENAMBAHKAN CADIK UNTUK MENINGKATKAN SURVIVAL OF INTACT STABILITY
}

\author{
Modification of a 30 GT Purse Seiner with Outrigger Addition to Improve Survival Intact \\ Stability \\ Oleh: \\ Hasanudin $^{1 *}$, Totok Yulianto ${ }^{1}$, Rizky Chandra Ariesta ${ }^{1}$ \\ ${ }^{1}$ Institut Teknologi Sepuluh Nopember, Jalan Raya Institut Teknologi Sepuluh Nopember, \\ Surabaya, Indonesia \\ *Korespondensi: hasanudin@na.its.ac.id
}

Diterima: 9 Agustus 2019; Disetujui: 24 Oktober 2019

\begin{abstract}
A fishing operation is a dangerous and high risk activity. Stability of the vessel plays an important role in performing safely and successfully fishing operations. A brand new 30 GT purse seiner, production of a traditional shipyard in Batang Regency, experienced $15^{\circ}$ heel after its launch. This condition potentially affects the stability of the vessel. The purpose of the study is to analyze the vessel stability and improve existing stability by adding outriggers. Research was conducted in two phases, data collection in the research site and stability analysed using a naval architecture software. The vessel stability was analyzed in six loading scenarios following the fishing operation process, subsequently the stability was compared against IMO standard. Results show that with the existing design, the vessel does not meet IMO criteria for the most applied scenarios. Next step, outriggers were added in both sides of the vessel model, as an effort to improve its stability. Accordingly, it is revealed that outriggers addition is scientifically proven to improve the stability of the studied vessel. As this research merely focused on the stability improvement, further analysis regarding maneuverability is required given a purse seiner operates encircled fishing gear.
\end{abstract}

Keywords: outrigger, purse seiner, stability

\section{ABSTRAK}

Operasi penangkapan ikan di laut dengan menggunakan kapal merupakan aktivitas yang berbahaya dan memiliki risiko kecelakaan yang tinggi. Keselamatan dan keberhasilan suatu operasi penangkapan ikan sangat dipengaruhi oleh stabilitas kapal yang baik. Sebuah kapal Purse seine 30 GT produksi galangan di Kabupaten Batang diketahui mengalami kemiringan $\pm 15^{\circ}$ pada saat pertama kali diluncurkan. Kondisi tersebut berpotensi mempengaruhi kualitas stabilitas kapal. Penelitian ini bertujuan untuk menganalisis stabilitas kapal purse seine 30 GT dan melakukan upaya peningkatan kualitas stabilitasnya dengan cara menambahkan cadik. Penelitian dilakukan dalam dua tahap yaitu: pengambilan data ukuran kapal di lokasi penelitian dan analisa stabilitas dengan menggunakan software arsitektur perkapalan. Perhitungan stabilitas dilakukan pada lima variasi pembebanan sesuai dengan proses operasi penangkapan ikan dan kualitas stabilitas dilihat berdasarkan kesesuaiannya dengan standard IMO. Hasil penelitian menunjukkan bahwa pada kondisi eksisting, hampir semua skenario pemuatan kapal tidak memenuhi kriteria IMO. Selanjutnya, modifikasi dilakukan dengan menambahkan cadik pada kedua sisi kanan dan kiri kapal. Berdasarkan hasil perhitungan, diketahui bahwa penambahan cadik terbukti dapat meningkatkan kualitas 
stabilitas dari kapal purse seine yang diteliti. Penelitian ini masih terbatas pada analisis kualitas stabilitas, karenanya perhitungan lanjutan terkait dengan kemampuan maneuver kapal masih perlu dilakukan, mengingat kapal ini beroperasi dengan cara melingkar alat tangkap.

Kata kunci: cadik, kapal purse seine, stabilitas

\section{PENDAHULUAN}

Sektor perikanan merupakan salah satu komoditas yang memberikan sumbangsih besar pada perekonomian dunia. Upaya untuk memanfaatkan dan mengeksploitasinya membutuhkan sarana berupa kapal (Ariesta et al. 2018). Kegiatan penangkapan ikan di laut dengan kapal merupakan pekerjaan yang berbahaya (danger), kotor (dirty) dan sulit (difficult) sehingga dikenal dengan profesi 3D. Risiko terjadinya kecelakaan sangatlah tinggi yang dapat disebabkan oleh kurangnya kualitas sumber daya manusia, ukuran kapal ikan yang relatif kecil, kondisi cuaca yang tidak bersahabat dan tuntutan untuk tetap beroperasi dengan menarik alat tangkap beserta hasil tangkapannya. Ditambah lagi cuaca yang semakin sulit diprediksi akhir-akhir ini berpotensi meningkatkan resiko kecelakaan kapal.

Keselamatan operasi kapal ikan tergantung pada beberapa faktor yaitu: human (nakhoda dan anak buah kapal), machines (kapal dan peralatan keselamatan) dan environment (lingkungan) (Jasman 2015; Santara et al. 2014. Hasil penelitian yang dilakukan oleh Suwardjo et al. (2010a) dan Suwardjo et al. (2010b) menyebutkan bahwa kecelakaan kapal umumnya disebabkan karena adanya kegagalan salah satu atau kombinasi beberapa faktor penyebab di atas. Data kecelakaan yang dihimpun dari PPN Pekalongan, PPS Cilacap dan PPP Tegalsari menunjukkan bahwa tingkat kecelakaan fatal di ketiga wilayah tersebut tercatat 115 orang meninggal pertahun dari 100.000 awak kapal. Angka tersebut lebih tinggi dibandingkan data global yang mencapai 80 orang per tahun dari 100.000 awak kapal. Temuan ini menegaskan perlunya upaya untuk meningkatkan aspek keselamatan kapal ikan yang diharapkan dapat menurunkan angka kecelakaan dan korban jiwa di laut.

Stabilitas kapal yang baik menentukan keselamatan kapal dan keberhasilan suatu operasi penangkapan ikan. Salah satu faktor yang menentukan tinggi atau rendahnya kemampuan stabilitas suatu kapal adalah penempatan muatan dan distribusi berat di geladak kapal (Lizzi 1983; Nurdin et al. 2017). Umumnya nelayan tradisional sering mengabaikan penempatan muatan dan hanya menggunakan intuisi dan kebiasaan untuk menata muatan tersebut. Selain itu, kelebihan muatan dapat mengurangi kualitas stabilitas kapal, karena akan memperkecil freeboard (daya apung cadangan) (Susanto et al. 2011). Pengaturan muatan yang baik, dapat merubah posisi titik berat kapal sehingga akan meningkatkan survival intact stability. Stabilitas berbagai macam operasi kapal harus dipenuhi untuk menjamin keselamatan kapal.

Peningkatan kualitas stabilitas juga dapat dilakukan melalui upaya modifikasi kapal (Barus et al. 2013; Sianturi \& Permana 2013). Sebuah kapal purse seine 30 GT yang baru selesai di bangun secara tradisional di Kabupaten Batang, diketahui mengalami heel (miring berle-bih) $\pm 15^{\circ}$ ketika pertama kali diluncurkan. Kondisi ini tentunya berbahaya untuk kinerja kapal tersebut saat dioperasikan. Penelitian ini dilakukan dengan menganalisis tingkat stabilitas kapal eksisting berbagai kondisi pelayaran dan melakukan perbaikan stabilitas kapal eksisting dengan penambahan cadik di bagian kanan dan kiri badan kapal.

\section{METODE}

Penelitian dilaksanakan di galangan kapal kayu tradisional terletak di kabupaten Batang, Provinsi Jawa Tengah. Kapal yang di kaji adalah kapal kayu purse seine 30 GT bantuan INKA MINA yang baru selesai dibangun di galangan setempat seperti yang terlihat pada Gambar 1 .

Tahapan pertama dalam penelitian adalah mengumpulkan data berupa gambar sketsa dan ukuran kapal, yang meliputi dimensi utama kapal dan koordinat lambung kapal. Alat yang digunakan untuk mengukur berupa: meteran, benang, dan waterpass. Berdasarkan informasi awal yang telah diverifikasi oleh narasumber, kapal ikan ini mengalami hee/ketika pertama kali diluncurkan.

Tahapan selanjutnya adalah pemodelan lambung kapal dengan bantuan software Maxsurf Modeler Connect Edition 22. Pada tahapan ini, hasil sketsa dan pengukuran koordinat kapal di lapangan, direkonstruksi ulang untuk mendapatkan model lambung yang menyerupai bentuk 
kapal aslinya. Hasil pemodelan divalidasi dengan hasil perkiraan berat kapal kosong dan berat muatan yang dapat diangkut olek kapal. Selanjutnya, dilakukan pemodelan untuk semua tangki dan kompartemen yang ada di kapal seperti yang dilakukan oleh Ahmed et al. (2012).

Berat kapal terdiri dari komponen berat kapal kosong (LWT) dan berat bobot mati kapal (DWT). LWT merupakan berat yang tetap terdiri dari berat lambung, permesinan, peralatan dan perlengkapan yang terpasang di kapal. Sementara itu, DWT merupakan berat yang berubah tergantung pada operasi kapal terdiri dari berat muatan, bahan bakar, air tawar dan perbekalan makanan.

Pengukuran kualitas stabilitas kapal perlu dilakukan dengan beberapa skenario operasi untuk menjamin keselamatan kapal (Novita et al. 2016). Pada penelitian ini, pengujian dilakukan pada kondisi pembebanan yang berbeda-beda. Variasi kondisi pembebanan kapal tergantung pada variasi DWT saat operasi seperti yang disajikan pada Tabel 1. Penjelasan variasi kondisi pembebanan pada Tabel 1 adalah sebagai berikut:

- Kondisi l: kapal kosong dimana kapal berada di pelabuhan, tidak membawa muatan dan tidak membawa bahan bakar.

- Kondisi II: kapal berangkat dimana kapal membawa bahan bakar penuh, dan membawa air ballast sebagai ganti muatan agar semua bagian balingbaling kapal masuk ke dalam air.

- Kondisi III: kapal melakukan penangkapan, memuat $50 \%$ ikan di ruang palkanya, dan bahan bakar tersisa $70 \%$ dari total kapasitasnya.

- Kondisi IV: kapal meninggalkan daerah penangkapan ikan dengan memuat $100 \%$ ikan di ruang palkanya, dan bahan bakar tinggal $50 \%$ dari total kapasitasnya.
- Kondisi V: kapal pulang dimana kapal telah tiba di pelabuhan, menurunkan muatannya dan bahan bakar tersisa $30 \%$ dari total kapasitasnya.

Perhitungan stabilitas kapal menggunakan prinsip kesetimbangan gaya dan momen. Ketika kapal mengapung di atas permukaan air, bekerja dua jenis gaya yang sama besar yaitu: gaya berat $(\mathrm{G})$ yang arahnya ke bawah dan gaya apung (B) yang arahnya ke atas. Ketika kapal berlayar, kapal akan menerima gaya dari luar berupa angin dan gelombang, yang akan membuat kapal oleng (Gambar 2).

Gaya B dan G mula-mula terletak pada satu garis lurus di centerline, namun saat mendapat gaya dari luar kapal akan miring. Posisi tersebut membuat gaya $\mathrm{B}$ akan berpindah menyesuaikan bentuk badan kapal yang masuk ke dalam air, sedangkan gaya $\mathrm{G}$ posisinya tetap tetapi arahnya tidak lagi segaris dengan centerline. Saat gaya luar hilang, gaya berat dan gaya apung akan membentuk momen kopel dan lengan momen kopel kedua gaya tersebut disebut GZ seperti pada Gambar 2. Jika lengan GZ ini positif kapal akan mampu kembali ke posisi semula (stabil) dan jika GZ negatif maka kapal akan terbalik (labil) setelah gaya dari luar hilang (Muh et al. 2017).

Nilai GZ positif belum tentu menjamin kapal tidak akan terbalik. International Maritime Organization (IMO) telah menetapkan kriteria stabilitas kapal dalam peraturan A.749 Code on Intact Stability 2008 (IS 2008), dimana di dalamnya termasuk kriteria stabilitas kapal ikan (IMO 1990). Software Maxsurf Stability Connect Edition 22, yang digunakan dalam penelitian ini, dapat memodelkan bentuk badan kapal beserta tangki-tangkinya, menghitung kurva stabilitas kapal dan mengukur survival intact stability kapal dengan menggunakan IS 2008.

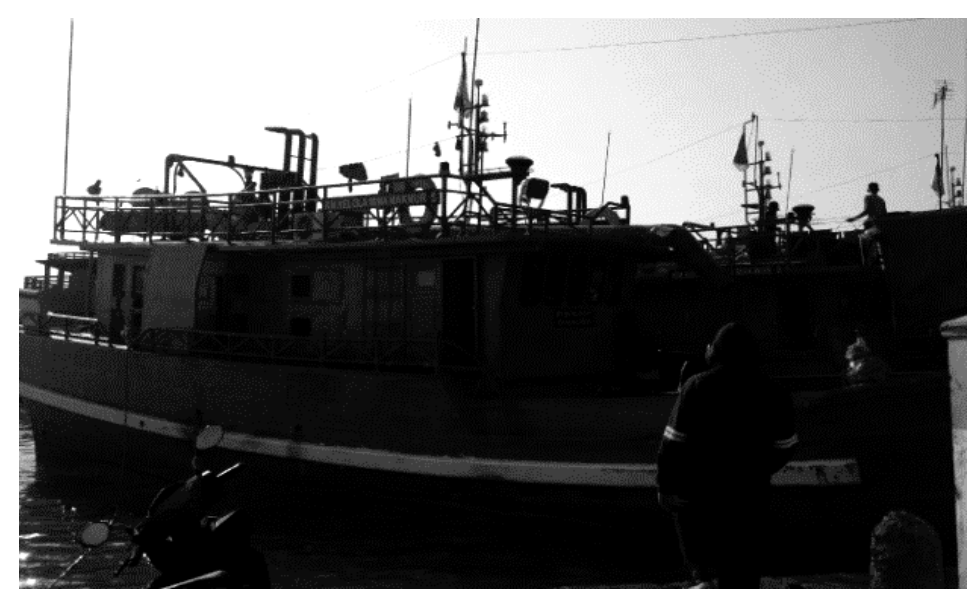


Gambar 1 Kapal ikan 30 GT

Tabel 1 Variasi kondisi pembebanan kapal ikan 30 GT purse seine sesuai dengan operasinya

\begin{tabular}{ccc}
\hline Kondisi Pembebanan & \multicolumn{2}{c}{ Bobot mati kapal (\%) } \\
& Bahan Bakar & Muatan \\
\hline Kondisi I & $0 \%$ & $0 \%$ \\
\hline Kondisi II & $100 \%$ & $20 \%$ \\
\hline Kondisi III & $70 \%$ & $50 \%$ \\
\hline Kondisi IV & $50 \%$ & $100 \%$ \\
\hline Kondisi V & $30 \%$ & $0 \%$
\end{tabular}

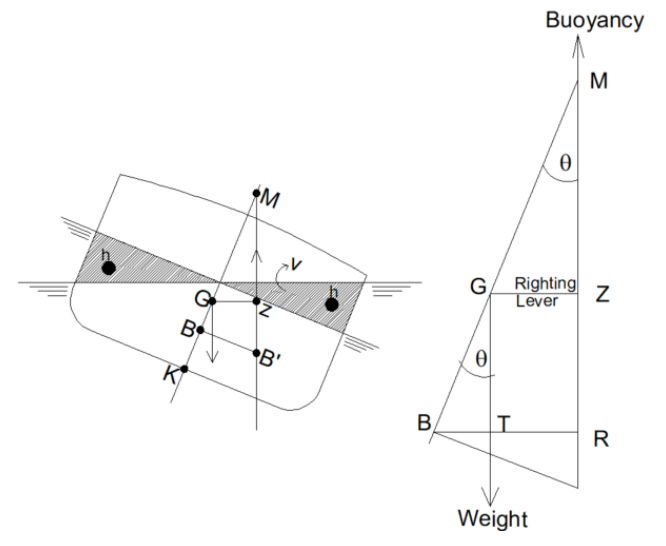

Gambar 2 Lengan stabilitas (Tupper 2004)

\section{HASIL DAN PEMBAHASAN}

\section{Hasil Survey Ukuran Utama Kapal}

Ukuran utama kapal memiliki pengaruh besar terhadap kapasitas muat, performa dan keselamatan kapal. Kualitas stabilitas kapal dapat dipengaruhi oleh rasio L/B yang terkait dengan penambahan lengan $\mathrm{GZ}$ dan $\mathrm{H} / \mathrm{T}$ yang terkait dengan freeboard. Hasil pengukuran kapal langsung di lapangan didapatkan bahwa ukuran utama kapal seperti yang terlihat pada Tabel 2. Panjang kapal total adalah 19,5 meter, panjang deck 17,45 meter, lebar 4,7 meter, dalam 2,2 meter, dan sarat 1,8 meter. Panjang kapal purse seine dalam penelitian ini di bawah 24 meter dimana untuk peraturan konstruksi dan keselamatan tidak wajib mengikuti aturan dari biro klasifikasi Indonesia.

\section{Hasil Pemodelan Lambung}

Pemodelan lambung dibuat dalam tiga dimensi menyerupai bentuk lambung kapal eksisting. Pemodelan ini memungkinkan lambung kapal dapat dilihat dari berbagai sudut pandang seperti Gambar 3 yang menunjukkan lambung tampak depan (a) dan lambung dari sudut pan- dang lainnya (b). Pemodelan tiga dimensi ini dilakukan untuk menjamin smoothing lambung dan menjamin keakuratan koordinatnya dibandingkan dengan pemodelan menggunakan gambar dua dimensi.

Hasil pemodelan lambung tiga dimensi selanjutnya diubah menjadi gambar dua dimensi berbentuk rencana garis seperti yang terlihat pada Gambar 4. Terlihat bahwa body plan kapal ikan ini mempunyai berbentuk round bilge yang langsing. Bagian depan kapal terdapat haluan berbentuk bentuk V. Sementara itu, di bagian buritan kapal berbentuk $U$ dengan transom yang panjang yang di bawahnya diletakkan skeg untuk memisahkan aliran air dari balingbalingkanan dan kiri kapal. Kapal mempunyai sheer buritan yang lebih tinggi daripada sheer haluan, ini tidak seperti kapal umumnya sehingga akan berpengaruh pada perhitungan freeboard kapal.

\section{Hasil Pemodelan Rencana Umum}

Hasil survey dengan melakukan pengukuran kemudian dibuat sketsa menjadi layout ruangan-ruangan, kemudian digabung dengan pemodelan lambung menjadi rencana umum seperti yang terlihat pada Gambar 5. Adapun 
layout rencana umum kapal secara garis besar terdiri dari: lambung kapal di bawah geladak utama dan ruang akomodasi yang terletak di atas geladak utama kapal. Ruangan lambung kapal dibagi menjadi: ruang air tawar, ruang jaring, tangki harian, ruang mesin, ruang pendingin, palka dan ruang kosong pada diceruk haluan. Di bawah tangki air tawar terdapat kemudi dan di bawah ruang jaring terdapat propeller kapal. Pada ruang akomodasi menjadi satu antara ruang kemudi dan ruang tidurnya anak buah kapal. Di belakang ruang akomodasi terdapat ruang untuk menata jaring dan tali agar tidak terbelit.

\section{Tinjauan Perbaikan Stabilitas Kapal}

Berdasarkan hasil survey ditemukan fakta bahwa ketika kapal kosong pertama kali diluncurkan mengalami heel $\pm 15^{\circ}$ dengan kondisi pembebanan membawa jaring, tanpa muatan dan tanpa bahan bakar. Kondisi ini sangat membahayakan jika kapal digunakan untuk berlayar. Hal ini diakibatkan karena adanya penataan pembebanan yang tidak tepat, titik berat muatan yang terlalu tinggi dan dimensi ukuran utama kapal yang kurang proporsional. Hal ini terjadi karena pada saat proses desain kapal tidak dilakukan perhitungan stabilitas dan kapal dibangun dengan sistem tradisional.

Perbaikan stabilitas dengan mengatur ulang tata letak muatan jaring di rencana umum telah dilakukan, tetapi tidak menambah kemam- puan stabilitas kapal secara signifikan. Penelitian yang dilakukan oleh Tremblay (2018) menyebutkan bahwa stabilitas kapal ikan dapat diperbaiki dengan menambahkan sponsons (bouyancy) di sebelah kanan dan kiri lambung kapal di atas garis air yang berfungsi untuk meningkatkan daya apung cadangan. Sehingga, ketika mengalami heel kapal akan ditahan oleh sponsons tersebut. Kontruksi sponsons mirip dengan konstruksi lambung kapal baru yang membutuhkan kekedapan yang tinggi. Perbaikan stabilitas kapal purse seine dengan menambahkan sponsons atau menambah lebar kapal tidak memungkinkan karena akan menambah GT, menambah kontruksi dan menambah biaya pembangunan kapal yang cukup tinggi.

Memperhitungkan kondisi di atas, perbaikan stabilitas yang mungkin dilakukan adalah dengan menambah cadik seperti yang dilakukan pada kapal tradisional. Cadik berfungsi sama dengan sponsons. Penambahan cadik merupakan budaya nenek moyang untuk memperbaiki stabilitas kapal, tetapi belum dibuktikan secara ilmiah dan hanya dilakukan berdasarkan intuisi. Pada paper ini dilakukan simulasi penambahan cadik untuk membuktikan keefektifan penggunaan cara tradisional pada lambung kapal yang menjadi objek penelitian. Penambahan cadik pada lambung kapal seolah-olah menjadikan kapal berlambung trimaran (memiliki tiga lambung) sehingga kapal tidak mudah terbalik. Gambar 6a merupakan kapal existing tanpa cadik dan Gambar 6b adalah setelah diberi cadik.

Tabel 2 Dimensi ukuran utama kapal ikan 30 GT purse seine

\begin{tabular}{lccc}
\hline Item Ukuran Utama & Symbol & Dimensi & Satuan \\
\hline Length Overall & LOA & 19.5 & meter \\
Length of Deck & LOD & 17.45 & meter \\
Breadh & $\mathrm{B}$ & 4.7 & meter \\
Depth & $\mathrm{D}$ & 2.2 & meter \\
Draft & $\mathrm{T}$ & 1.8 & meter \\
Block Coefficient & $\mathrm{Cb}$ & 0.473 & \\
\hline
\end{tabular}

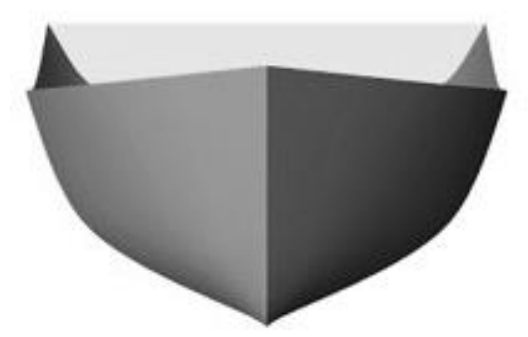

(a)

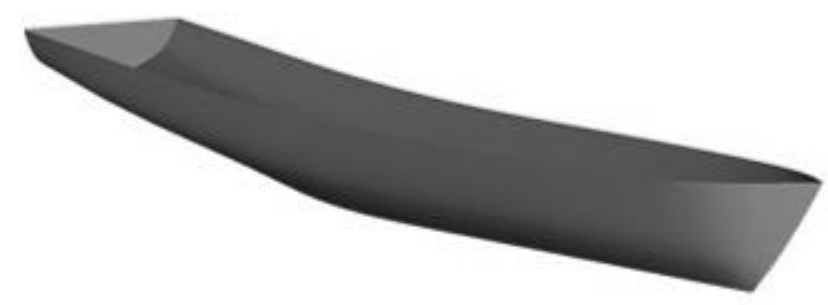

(b)

Gambar 3 Pemodelan lambung 3D kapal ikan 30 GT (a) tampak depan (b) tampak perspektif 


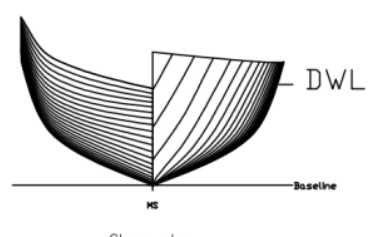

Sheer plan

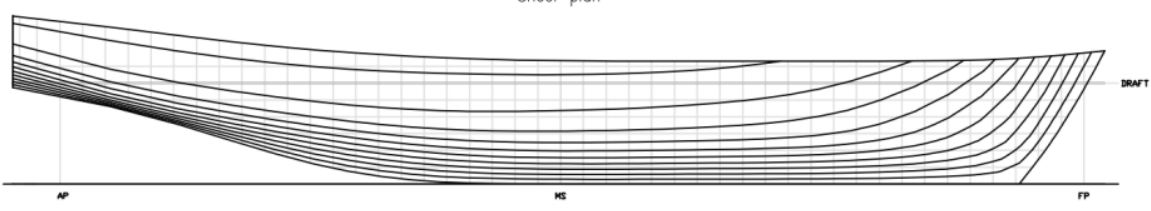

Half Breadth Plan

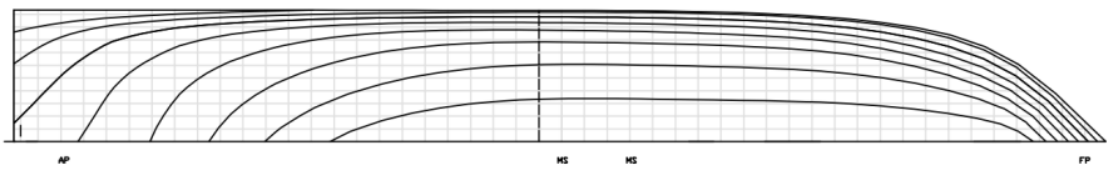

Gambar 4 Rencana garis kapal ikan 30 GT
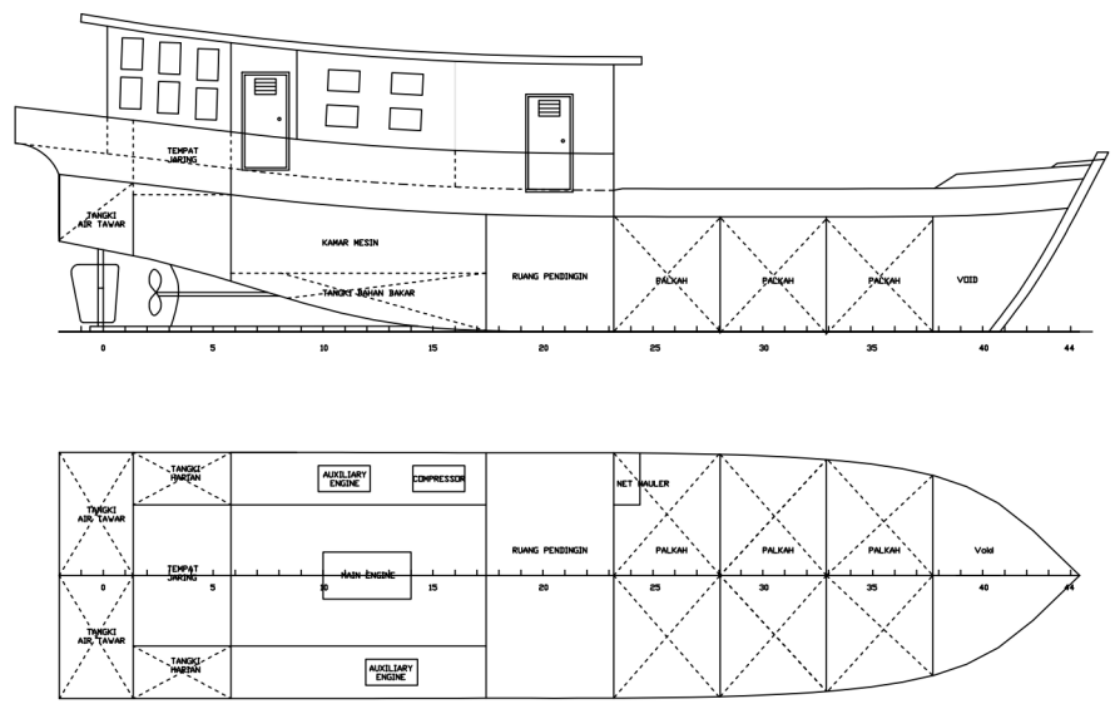

Gambar 5 Rencana umum kapal ikan 30 GT
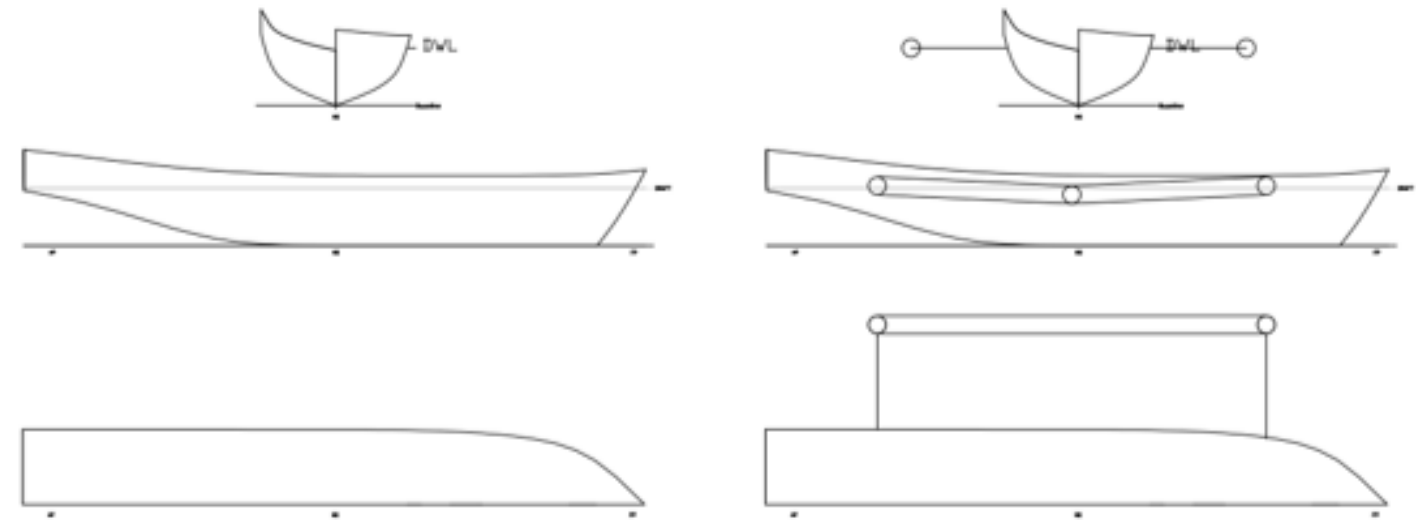

(a)

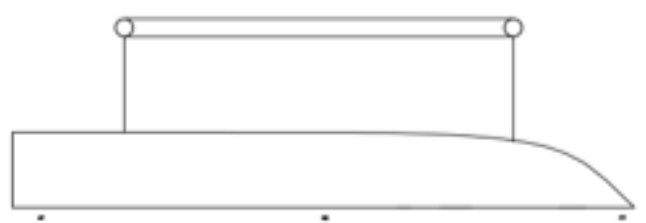

(b)

Gambar 6 (a) Lambung kapal eksisting (b) lambung kapal dengan cadik 


\section{Tinjauan Operasional Kapal dengan Cadik}

Penambahan cadik pada lambung kapal yang langsing mempunyai pengaruh positif untuk meningkatkan stabilitas kapal, cadik akan menahan kapal supaya tidak mudah terbalik ke kanan atau ke kiri ketika mendapatkan gangguan gaya dari luar. Akan tetapi pemasangan cadik mempunyai pengaruh yang negatif akan menambah hambatan kapal, menaikan radius putar manuver dan memperlambat operasional penangkapan ikan. Pada paper ini penentuan ukuran cadik dipertimbangkan berdasarkan aspek penambahan kebutuhan survival intact stability dan sedihit mungkin penambahan tahanan pada kapal. Dimensi cadik didesain dengan diameter $0,28 \mathrm{~m}$, panjang $12,7 \mathrm{~m}$ dan jarak salah satu sisi cadik dari lambung luar 3 meter.

Sebagai kapal pure-siene dengan metode penangkapan melingkari fishing ground, penggunaan cadik akan menjadi kendala tersendiri karena mempengaruhi kinerjanya dalam bermanuver. Kajian penambahan cadik terhadap turning ability pada kapal purse seine pada paper ini tidak dilakukan. Akan tetapi masalah ini dapat diatasi dengan manajemen operasi seperti yang ditunjukkan pada Gambar 7. Bukti di lapangan juga menunjukkan bahwa terdapat banyak kapal tradisional memilik cadik pada satu sisi atau dua sisi lambung kapal yang tidak terkendala masalah tersebut.

\section{Tinjauan Stabilitas Kapal tanpa Cadik}

Perhitungan kualitas stabilitas dilakukan pada berbagai kondisi pembebanan seperti yang disajikan pada Tabel 1 dan hasilnya ditampilkan pada Tabel 3. Kolom pertama menunjukkan kriteria IS 2008, sedangkan kolom kedua menunjukkan nilai kriteria IS 2008. Sementara itu, kolom ketiga sampai kolom keenam merupakan variasi pembebanan sesuai Tabel 1. Pada Tabel 3, angka dalam kurung mengindikasikan nilai tersebut tidak memenuhi kriteria IS 2008 dan pada baris paling bawah merupakan kesimpulan dari kualitas stabilitas kapal secara umum.

Berdasarkan Tabel 3 terlihat secara umum, bahwa kapal purse seine yang diteliti tidak memenuhi kriteria IS 2008 pada hampir semua kondisi pembebanan kecuali kondisi IV.
Untuk kriteria luas area kurva GZ 0 --30 hanya kondisi IV saja yang memenuhi IS 2008 dimana nilainya $4,59 \geq 3,15 \mathrm{~m}$.rad. Untuk kriteria luas area kurva GZ $0^{\circ}-40^{\circ}$ hanya kondisi III saja yang tidak memenuhi IS 2008 dimana nilainya 4,59 $\leq$ 5,15 m.rad. Sementara itu, luas area kurva GZ $30^{\circ}-40^{\circ} \geq 1,72 \mathrm{~m} \cdot \mathrm{rad}, \mathrm{GZ}$ max pada sudut $30^{\circ} \geq$ $0,200 \mathrm{~m}$, Sudut $\mathrm{GZ} \max \geq 25^{\circ}$ dan $\mathrm{GM}_{0} \geq 0,150 \mathrm{~m}$ semua kondisi memenuhi kriteria IS 2008. Apabila terdapat salah satu kriteria yang tidak memenuhi, maka kapal beresiko tinggi terbalik ketika beroperasi di laut. Semua kondisi pembebanan atau operasional seharusnya memenuhi semua kriteria dari IS 2008. Hasil perhitungan stabilitas di atas menegaskan perlunya modifikasi kapal.

\section{Tinjauan Stabilitas Kapal dengan Cadik}

Tabel 4 menunjukkan hasil analisis stabilitas dari kapal yang telah dimodifikasi dengan penambahan cadik. Berdasarkan Tabel 4 dapat dilihat bahwa pada semua kondisi pembebanan, kapal dengan cadik memenuhi kriteria IS 2008. Perbandingan antara Tabel 3 dengan Tabel 4 memperlihatkan adanya peningkatan nilai kriteria stabilitas kapal. Pada kriteria luas area kurva GZ $0^{\circ}-30^{\circ}$ terjadi peningkatan yang cukup signifikan $59,5 \%$ pada kondisi I dan peningkatan terendah $28,9 \%$ pada kondisi IV. Untuk area kurva GZ $00^{\circ}-40^{\circ}$ peningkatan sebesar $47,7 \%$ pada kondisi I merupakan nilai tertinggi, sedangkan nilai terendahnya ditemukan pada kondisi III dengan nilai $15 \%$. Untuk area kurva GZ $30^{\circ}-40^{\circ}$ peningkatan tertinggi sebesar $32,9 \%$ terdapat pada kondisi I, sebaliknya kondisi II justru menunjukkan penurunan kualitas sebesar $5,7 \%$. Meskipun demikian, kualitas stabilitas pada pembebanan kondisi II masih tergolong aman. Perbandingan Tabel 3 dan 4 pada ketiga kriteria yang lain yaitu $\mathrm{GZ}_{\max }$ pada sudut $30^{\circ}$, Sudut $\mathrm{GZ}_{\max }$ dan $\mathrm{GM}_{0}$ menunjukkan terdapat kenaikan pada kondisi I dan penurunan pada kondisi lainnya. Secara umum perbandingan kedua tabel tersebut menunjukkan bahwa penambahan cadik di sisi kanan dan kiri lambung akan meningkatkan survival intact stability kapal, sehingga kapal dengan cadik lebih aman dari kemungkinan terbalik.

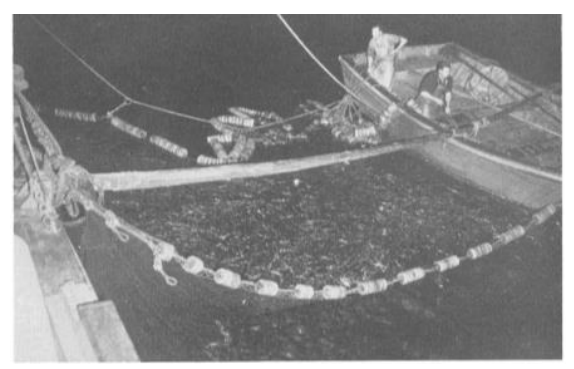

Gambar 6 Operasional kapal dengan penambahan cadik (Scofield 1951) 
Tabel 3 Hasil perhitungan stabilitas kapal existing

\begin{tabular}{llccccc}
\hline \multicolumn{1}{c}{ Kriteria } & Nilai IS 2008 & Kondisi I & Kondisi II & Kondisi III & Kondisi IV & Kondisi V \\
\hline Area $0^{\circ}-30^{\circ}$ & $\geq 3,15 \mathrm{~m} . \mathrm{rad}$ & $(2,41)$ & $(2,36)$ & $(2,41)$ & 4,59 & $(3,00)$ \\
Area $0^{\circ}-40^{\circ}$ & $\geq 5,15 \mathrm{~m} . \mathrm{rad}$ & 5,59 & 5,13 & $(5,07)$ & 8,45 & 6,61 \\
Area $30^{\circ}-40^{\circ}$ & $\geq 1.72 \mathrm{~m} . \mathrm{rad}$ & 3,18 & 2,78 & 2,66 & 3,86 & 3,60 \\
GZ & 0,350 & 0,288 & 0,271 & 0,394 & 0,401 \\
Sudut GZ & & 42,7 & 39,1 & 37,3 & 39,1 & 44,5 \\
GMo & $\geq 25^{\circ}$ & 0,983 & 0,876 & 0,813 & 1,008 & 1,067 \\
\hline IMO Criteria & & Fail & Fail & Fail & Pass & Fail \\
\hline
\end{tabular}

Tabel 4 Hasil perhitungan stabilitas kapal dengan cadik

\begin{tabular}{llccccc}
\hline Kriteria & Nilai IS 2008 & Kondisi I & Kondisi II & Kondisi III & Kondisi IV & Kondisi V \\
\hline Area $0^{\circ}-30^{\circ}$ & $\geq 3,15 \mathrm{~m} \cdot \mathrm{rad}$ & 5,95 & 3,52 & 3,46 & 6,46 & 5,63 \\
Area $0^{\circ}-40^{\circ}$ & $\geq 5,15 \mathrm{~m} \cdot \mathrm{rad}$ & 10,70 & 6,16 & 5,97 & 10,93 & 10,09 \\
Area $30^{\circ}-40^{\circ}$ & $\geq 1,72 \mathrm{~m} \cdot \mathrm{rad}$ & 4,74 & 2,63 & 2,51 & 4,46 & 4,45 \\
GZmax Sudut 30ㅇ & $\geq 0,200 \mathrm{~m}$ & 0,516 & 0,267 & 0,256 & 0,453 & 0,475 \\
Sudut GZmax & $\geq 25^{\circ}$ & 44,5 & 35,5 & 33,6 & 37,3 & 42,7 \\
GMo & $\geq 0,150 \mathrm{~m}$ & 1,107 & 0,713 & 0,661 & 1,004 & 1,056 \\
\hline IMO Criteria & & Pass & Pass & Pass & Pass & Pass \\
\hline
\end{tabular}

\section{KESIMPULAN}

Berdasarkan hasil analisis, diketahui bahwa: Pada hampir semua kondisi pembebanan, stabilitas kapal tanpa cadik tidak memenuhi kriteria IS 2008, terutama pada kriteria luas area kurva GZ 0-30 m.rad. Penambahan cadik pada sisi kiri dan kanan secara umum dapat meningkatkan kualitas stabilitas kapal, sehingga dapat dikatakan bahwa kapal dengan cadik lebih stabil dibandingkan yang tanpa cadik. Dimensi cadik yang dipasang diameter $0.28 \mathrm{~m}$, panjang $12.7 \mathrm{~m}$ dan jarak salah satu sisi cadik dari lambung luar 3 meter. Penelitian ini membuktikan bahwa metode penambahan cadik yang biasa diaplikasikan pada kapal ikan skala kecil dapat diterapkan pada kapal purse seine 30 GT untuk peningkatan survival stabilitas kapal.

\section{SARAN}

Paper ini secara umum membahas keselamatan kapal purse seine 30 GT dengan cara menambahkan cadik pada lambung kapal untuk meningkatkan survival stabilitas kapal. Peneliti-peneliti selanjutnya perlu melengkapi kajian performance kapal yang dihubungkan dengan: pengaruh penambahan cadik terhadap penambahan tahanan dan kebutuhan power kapal, dan pengaruh penambahan cadik terhadap kemampuan manuver kapal.

\section{UCAPAN TERIMA KASIH}

Ucapan trimakasih diberikan kepada Laboratorium Desain Kapal, Teknik Perkapalan, Fakultas Teknologi Kelautan, Institut Teknologi Sepuluh Nopember (ITS) yang telah memberikan fasilitas berupa computer dan software Maxsurf Modeler dan Stability Connect Edition 22 untuk menyelesaikan paper ini.

\section{DAFTAR PUSTAKA}

Ahmed Y, Jamail A, Yaakob O. 2012. Boat Survey Using Photogrammetry Method. Int Rev Mech Eng. 6(7): 1643-1647.

Ariesta RC, Arif MS, Puspitasari HP. 2018. Comparison of Economical Analysis of Wood and Fiberglass Vessels in Randuboto Village, Gresik Regency, East Jave. ECSOFiM: Journal of Economic and Social of Fisheries and Marine. 1: 73-82.

Barus AB, Santosa AWB, Jatmiko S. 2013. Modifikasi Kapal Ikan Fiberglass Monohull Menjadi Catamaran untuk Perairan Pantai Teluk Penyu Cilacap. Junal Teknik Perkapalan 1(1): [online] 
IMO. 1990. Intact Stability Code. Assembly Res. A. 749. London: International Maritime Organization.

Jasman, T. 2015. Aspek Keselamatan Kerja Kapal Purse Seine di Tempat Pelelangan Ikan Pelabuhan Kota Tegal. Oceatek 9(1): 103-112.

Lizzi H. 1983. Stability and trim of fishing vessels. s.1: University of Rhode Island.

Muh AA, Iskandar BH, Novita Y. 2017. Kajian Desain Kapal Purse Seine Tradisional di Kabupa-ten Pinang (Studi Kasus KM. Cahaya Arafah). ALBACORE. 1(1): 6976.

Novita Y, Martiyani N, Ariyani R. 2016. Kualitas Stabilitas Kapal Payang Pelabuhan Ratu Berdasarkan Distribusi Muatan. Jurnal IPTEKS PSP. 1(1): 28-39.

Nurdin HS, Iskandar BH, Imron M, Novita Y. 2017. Pengaruh Distribusi Muatan terhadap Stabilitas Kapal Purse Seine Modifikasi di Kabupaten Bulukumba. Jurnal IPTEKS PSP. 4(7): 39-48.

Santara AG, Purwangka F, Iskandar BH. 2014. Peralatan Keselamatan Kerja pada Perahu Slerek di PPN Pengambengan, Kabupaten Jembrana, Bali. Jurnal IPTEKS PSP. 1(1): 53-68.

Scofield W. 1951. State of California Department of Fish and Game. Purse Seines and
Other Roundhaul Nets in California, June: 16.

Sianturi DSA, Permana SM. 2013. Analisis Stabilitas terhadap Operasional Desain Kapal 20 GT di Palabuhanratu. Jurnal Kelautan Nasional. 8(3): 120-126.

Susanto A, Iskandar BH. \& Imron M. 2011. Evaluasi Desain dan Stabilitas Kapal Penangkap Ikan di Pelabuhan Ratu (Studi Kasus Kapal PSP 01). Marine Fisheries: Journal of Marine Fisheries Technologyy and Management. 2(2): 213-221.

Suwardjo D, Haluan J, Jaya I, Soen'an, HP. 2010. Kajian Tingkat Kecelakan Fatal, Pencegahan dan Mitigasi Kecelakaan Kapal-Kapal Penangkap lkan yang Berbasis Operasi di PPP Tegalsari, PPN Pekalongan dan PPS Cilacap. Jurnal Teknologi Perikanan dan Kelautan. 1(1): 61-72.

Suwardjo D, Haluan J, Jaya I, Soen'an HP. 2010. Keselamatan Kapal Penangkap Ikan, Tinjauan dari Aspek Regulasi Nasional dan Internasional. Jurnal Teknologi Perikanan dan Kelautan. 1(2): 1-13.

Tremblay L. 2018. Guidelines for Fishing Vessel Major Modifications or a Change in Activity. Canada: Her Majesty the Queen in Right of Canada, as represented by the Minister of Transport.

Tupper E. 2004. Introduction to Naval Architecture Fourth Edition. London: Elsevier Ltd. 